\title{
Determination of Social Exclusion Among Young Syrian Refugees Living in Turkey
}

\author{
Orhan Kocak ${ }^{1 *}$, Ahmet Taha Arifoglu ${ }^{1}$, Mustafa Z Younis ${ }^{2}$
}

${ }^{1}$ Istanbul University-Cerrahpasa, Istanbul, TURKEY

${ }^{2}$ Jackson State University, USA

*Corresponding Author: orhan.kocak@istanbul.edu.tr

Citation: Kocak, O., Arifoglu, A. T. and Younis, M. Z. (2021). Determination of Social Exclusion Among Young Syrian Refugees Living in Turkey. European Journal of Environment and Public Health, 5(2), em0076. https://doi.org/10.21601/ejeph/10908

ARTICLE INFO

Received: 2 Dec. 2020

Accepted: 23 Jan. 2021

\begin{abstract}
After the Syria Conflict in 2011, Turkey has accepted about four million Syrian refugees. Initially, they were seen as guests, but after eight years, the Turkish Government has spent more than forty billion USD, and the money that has been spent is seen as a burden by both the Government and the people. That's why some Turkish people started using negative language against Syrian Refugees not only for economic reasons but also political. This study aims to understand the impact of young Syrian refugees' social exclusion with temporary protection status on their daily lives. It is thought that the stigmatization and negative discourses by the Society in which they live leads to social exclusion, and this has a fundamental effect on daily life practices. In this study, it is understood that Syrian Youth sometimes face exclusion and negative discourses in their daily lives in family, friends, education, and other fields. According to their statements, these exclusion situations differ according to their gender and education. Especially, women confront with some exclusion because of language and behaviors. Education should be used as a leverage to increase the integration between Turkish and Syrian People and integration policies based on multiculturalism must be produced to increase the harmony between two societies.
\end{abstract}

Keywords: Syrian immigrants, social exclusion, conditional refugees, refugee youth

\section{INTRODUCTION}

Although the basic definition of migration is defined as moving from one country to another, it is a complex psychosocial process with significant and tangible effects on an individual's identity and living. In fact, immigration brings deep losses to the person who performs this action. It gives immigrants a cognitively alien environment to abandon their culture, traditions, and language, which is internalized without questioning, and travel to the uncertainty (Akhtar, 2018).

The biggest problem of societies that accept immigrants is that the newcomer's view is incomplete or problematic (Erbaş, 2019). If host Society encounters the foreigner, it provides a conceptual framework to embody the foreigner. The definition of an encounter is linked to the concepts related to the participants' identities and the current social situations. Troublesome events often convey information that undermines or shadows the reputation of identities. Therefore, no matter how small these events are, they can weaken the whole design of the encounter, leaving traces to the parties what they will or will try to do in the next step (Goffman, 2018a).
Refugees confront with some kind of exclusions such as social and economic exclusion in the countries they go to. These are briefly, physical exclusion, failure to access their basic rights, language barriers, racism and cultural marginalisation (Taylor, 2004; Neil, 2008). Social and economic exclusion can be seen regularly in daily life as well as institutionally. Since refugees are excluded from the rights that should be granted, they are prevented from accessing employment, health services, housing and education (Taylor \& Stanovic, 2004). A study of Syrian immigrants in Lebanon found that social exclusion stems from poor housing and restricted access to labor markets (Sari et al., 2012). Exclusion from services and rights further increase the psychological problems of immigrants (Phillimore et al., 2003).

Many of the Syrian immigrants have been subjected to poverty because they cannot bring valuable assets of their own. Since they cannot meet many of their needs due to their poverty, their exclusion increases even more. However, some of them bringing their monetary savings or being educated contributes to the decrease of their exclusion. Various public surveys have shown that Syrian refugees are subject to social exclusion and continuously feel that they should go to their home countries. These feelings put more burden on Syrian, trauma and psychological distress, stigmatizes them, and 
prevents them from integrating into the Society they live in (Istanpol, 2019; Ekinci, 2015).

It has been understood that the refugees communicate more interactively with the people of the host country through education and employment. In this way, it was observed that they learned the foreign language quickly and gained their economic independence thanks to the wages they received. A study conducted with newly arrived immigrants in the UK found that employment and education provided significant social inclusion support (Phillimore \& Goodson, 2006).

The countries most affected by the Syrian civil war, which started in March 2011, are the neighboring countries. In this context, Turkey's most important problem to 4 million visitors fleeing civilians from the conflict that confronts (Sea, Ekinci, \& Hülür, 2016). Initially, public opinion in Turkey, although perceived as Syrian guests, Syrian mass migration after 2013, Foreigners and International Protection Act was enacted. In this way, Syrians are entitled to direct access to social, health, education, financial and moral support provided under the temporary protection status (Eren, 2018). Contrary to popular belief, Syrians are conditional refugees, not normal refugees. The law of foreign and international protection enables them to gain formal form by legally supporting this status. The number of Syrians in Turkey in September of 2019 as a temporary protection status was 3 million 666 thousand people (Multeciler Derneği, 2019).

The stigmatization of a foreigner gives rise to a problematic relationship. In many cases, when people meet, many moments in these relationships are moments when both sides must face stigmatizations' causes and consequences. The stigmatized individual may feel insecure about what people define about him/her as what kind of identity he will be given, and how he will be met (Goffman, 2014). Attitudes and behaviors against them effectively stigmatize immigrants in daily life (Erbaş, 2019).

The psychological trauma of escaping from the conflict in Syria has made many refugees extremely vulnerable. Besides, experts agree that time does not reduce trauma. Most trauma research experts think that the essence of both short and longterm traumas lies in repressed memories and emotions, especially in children. Syrians are psychologically disturbed and engaged in suicidal thoughts due to problems both in their own countries and in the countries they go. However, they can not to express these opinions due to cultural and religious reasons, and the possibility of stigma and exclusion (Saleh et al., 2018). Researches on this subject also emphasized that Syrians have problems in accessing psychological support (Hayata Destek Derneği, 2016). In this study, none of the interviewees stated that they received psychological support.

Youth is an essential factor that determines the future of every society. In this respect, the youngest, which is the most open to interaction with the Society, reflects the Society's potential on one side and its future on the other. In general, the Youth's place in the Society is due to its dynamism and the young will turn to the outside world in the youth stage (Sener, 2013). In this process, family, the environment, and the Society in which it is mutually acquired attitudes and behaviors must help. The young will establish relations with the outside world, understand and comprehend them according to the worldview, and interpret and take attitudes accordingly (Sener, 2013).

The social exclusion of Syrian Youth is deeply affecting them, and it is thought that if the relevant policy-makers cannot improve their solutions and proposals, this will cause problems for the whole Society. Determining and working on the conditions of the Syrian Youth for their solution and developing various solutions will help the Society to operate in a healthy way. In this sense, the scope of the article to increase awareness on the subject and put forward some advice for academics and policymakers.

\section{THE AIM OF THE STUDY}

The study's main purpose is to find out whether young Syrian refugees are exposed to social exclusion in their daily lives. If they are exposed to social exclusion, we will try to understand how and why it happens. The questions to be answered throughout the research are as follows;

- To what extent can young Syrian refugees be integrated into Turkish Society?

- How much do they feel free, safe, connected to Society in their relationships in school, work, and social life?

- Do Turkish People's behavior and discourses create pressure on Syrians?

- What are Syrians doing to reduce social exclusion?

\section{METHOD}

The main method of the article is the qualitative method. Qualitative research is most concerned with how people organize themselves and their environments, and how those who live in these environments make sense of their environment with symbols, rituals, social structures, social roles, and the like (Berg \& Lune, 2015). A semi structured interview technique was used as the interview method. This interview technique involves asking predetermined questions and addressing specific issues. These questions are asked consistently, but participants have the freedom to go beyond of them.

\section{THE SAMPLE}

The research sample consists of male and female Syrian refugee young people between 18-30 years of age who can speak Turkish and have temporary protection status in Sakarya province. Because of the size, inaccessibility, time limitation, and material limitation of the universe, a random and simple sampling method was used. This type of sample is based on the presence or availability of existing participants. The researcher visited places such as Istiklal and Arabacialani neighborhoods in the city and interviewed with Syrian Youth there. Syrian refugee youth outside of Sakarya was not accepted. Interviews with Turkish-speaking refugees were conducted and no interpreter support was received. 


\section{DATA COLLECTION AND PROCESSING}

After introducing the purpose of the research to the relevant participants, they were assured that their anonymity would be preserved. In this context, we did not ask for their names, surnames, e-mail addresses, residence addresses, and telephone numbers. Interviews with the participants started in October 2019 and ended at the end of October in 2019. Interviews with the participants took an average of 15-20 minutes. Interview recordings were transferred from the digital audio recording device to the computer and the recordings were transcribed into word files on the basis of each participant. During the interview, in addition to demographic questions such as age, participant's education, mother and father's education status, and worldview, each participant was asked the following questions.

- Do you want to talk and be friends with Turkish citizens?

- Do you think people in society treat you badly?

- Did you encounter any bad behavior and/or rhetoric lately?

- What do you think about Turkish individuals who communicate with you in society?

- What do you think when you are treated badly, does it affect your behavior and thinking negatively?

- Do you want to communicate or talk to any other Turkish citizen when you are mistreated?

In this qualitative study, descriptive and systematic analysis and interpretation approaches were utilized, and findings were evaluated. With the descriptive analysis used, the descriptive analysis of the data was presented by making direct excerpts from the individuals' words while adhering to the original forms of the data.

After determining some concepts and themes obtained from the systematic analysis, comparisons were made between them, and a systematic analysis of similarities and contradictions between them was tried. At the end of these interpretations, common tendencies in the findings were identified, and differences were tried to be revealed. It has been tried to reveal the hidden information and meanings in the details of the narrations.

\section{EDUCATIONAL STATUS OF} PARTICIPANTS

In 6 female participants, the number of people whose parents are university graduates is 3 . There is no one in the family of 4 male participants whose parents are university graduates. Also, no information or documents were requested. Families with university degrees sent their daughters to university. Other than this, a non-university family sent their daughters to university. Four out of six girls continue their university studies. Two of the boys are attending university education and the other two are not going to university.

\section{THE EFFECT OF SOCIAL EXCLUSION IN EVERYDAY LIFE OF FEMALE PARTICIPANTS}

Female participants think that Turkish citizens mistreat them because they think they are Syrians in the Society without any differences. When the relationship between mother and / or father is not a university graduate and having a university education, all Syrian female participants do not want to go out of their friendship circle.

22 Years Old, Female Participants, Equality, and Justice

"I usually make friends with those who share the same ideas and worldview with me. My friendship is more from my own country than the Turks. Of course, I talk to your people, but often because they are hard-minded to try to suppress me. So I don't usually talk to them. Since we are usually together with my friends, we speak Arabic.”

21 Years Old, Female, Equality

"In general, I realize that my peers are of the same opinion. Usually, these are from my country. It's not my choice. I usually talk to the Turks. There are many Turks in the place we live, some of them have bad discourses, yes. I usually don't act wrong, I try to understand them, and I don't try to force them to accept my own opinion. I love this community. I am familiar with your cultural values, and at the same time, Turkish Society is Muslim."

22 Years Old, Female Participant, Computer Engineering Student, Freedom and Justice

"I'm not closed to having different and negative views towards Syrians, we cannot expect everyone to be the same. But neither can I do disrespect to him about his thoughts, nor can he do to me. I want to talk to everyone, I don't want my friends to be from my own community, I want everyone to be in their own opinion, I respect, but I also expect to be respected. I speak my own language when I am in the family but I care to speak Turkish when I am in the community. But since I grew up in a structure where men are visible, I don't have any negative thoughts about the whole society"

23 Years Old, Female Participant, Electrical and Electronics Engineering Student, Freedom and Independence

"I usually choose the ones that are close to what I share. But I respect every opinion to anyone who approaches me and speaks. I want to be friends, share my thoughts, I want to talk, but generally, I can't speak very easily. I think it has not been read, not researched. Something about us needs to be known. Of course, we may not agree. They respond with dogmas. I usually try to speak Turkish while in the community, but I also speak Arabic. I usually want to talk and share, I want to be my friend, but I am having trouble speaking because of the impact of the current environmental factors." 
The female participants whose mother and/or father are university graduates and who are active undergraduate students have different and repetitive findings. Even if the family of university graduates thinks that Turks have misbehaved in their lives, they try to communicate with the Turks and speak Turkish in the community. From this point of view, it is thought that these participants' characteristics will give the most useful outputs within the scope of social adaptation programs developed for Syrian Youth.

As can be seen from the participants' discourse, psychological stress, and constant inability not to know what to do, and avoidance from negative behaviors become dominant over Syrian female participants. This situation is a major obstacle for educated Syrian women participants who can easily adapt to social cohesion within the research scope. In this sense, on the one side education is an important leverage for integration, on the other side, the attitudes of the host people are also important.

\section{THE EFFECT OF SOCIAL EXCLUSION ON THE DAILY PRACTICES OF MALE PARTICIPANTS}

Male Syrian participants think that they are experiencing social exclusion, whether they are active university students or under-university education. However, there is a more positive approach towards Turkey society. It represents a more extroverted and open group for interaction than female participants.

21 Years Old Male, Under-University Education, Conservative-Human Loving, Open-minded

\begin{abstract}
"First of all, I want to be my friend from all sides in this Society. I want him to think differently from me, think differently from me, and have different things. I don't think I've had any influence on my family about this. These experiences, going from one place to another, our people's European journey, what happened to Syria; these impressed me. I want to argue with people in Society who have very opposite ideas. I want to talk and discuss with people of all kinds, people of all walks of life. I don't usually speak my language in every environment. If there are Turks around, I try to speak Turkish but they usually look at me. That's why sometimes I feel strange and I don't know what to say. When this happens, I usually try to speak less or to speak Turkish in a lower voice. I was in Istanbul at first, then I came here. There is a constant change here, positive or negative, useful or useless."
\end{abstract}

25 Years Old, Male, International Relations Student, Liberal

"I can be friends with everyone. Maybe the situation I'm in has a serious impact. People have negative thoughts about us. So I usually talk to them to correct that impression. Because those who think like me, the Syrians, will say things close to me. I'm trying to talk to people of different perspectives. Yes, generally people's reactions to me are automated when they understand that I am from Syria. So I don't need to worry about it. But if a person is open to a relationship, the relationship will continue for me. I usually speak Arabic but there are some places, like my school, I speak Turkish, I care to talk to the people there and my Turkish friends. This Society attaches great importance to its culture. I'm trying to keep it alive myself. I support the State of Turkey and I am ready to sacrifice myself for this state."

Unlike the Syrian female participants, it was observed that they tried to act more openly and more interactively towards both their communities and Turkish people. This is related to the patriarchal society structure prevailing in Syrian Society and is thought to be related to the role of men in that Society. Even though they think that they are experiencing social exclusion, it is not thought that this creates psychological distress on them. Also, they are aware and admire that the Turkish State has supported and spent a lot of money on Syrians.

\section{CONCLUSIONS AND RECOMMENDATIONS}

If the family of the female participants and their educational level are under the university, the female participants tend to be more vulnerable to social exclusion and tend to close themselves further. Their use of Arabic is a stress reduction, and emotion-based coping strategy that they use to feel good, avoid an identity crisis. At the same time, they always establish friendship relationships among themselves. Although they sometimes have negative opinions about Turkish citizens, they love the Society and the social values of Turkish Society.

The situation is slightly different for women whose parents are university graduates and who go to university themselves. They think that they experience social exclusion in Society, but they also strive for social cohesion. They try to speak Turkish in public spaces, although they think that people mistreat them, they try to establish their relations with Turkish citizens in a timid manner. In this case, if they experience problems, they feel that they are more stressed psychologically. Although they are interested in social integration and want to make friends with the Turks simultaneously, this is not easy for them. Likewise, even if they sometimes feel excluded in Society, common social values such as Islam and history make them feel at home and on their own soil.

Male participants also think that they are exposed to social exclusion and are constantly exposed to bad thoughts and/or behavior in their relations with Turkish people. However, Syrian male asylum seekers do not have a negative opinion about Turkish citizens like female participants and always want to maintain communication with Turkish people. Generally, this communication serves Syrians' purpose and breaks the negative perceptions in Turkish society. From this perspective, the Syrian male refugees' coping strategy is primarily problem-oriented, an active coping strategy. This is 
thought to act within certain behavior/thought patterns because they come from a patriarchal society.

As a result, the female participants' social cohesion is directly related to the family's and their education level. There are efforts to increase the social cohesion among the female participants who are university graduates in their families. They are more prone to social cohesion, but their social exclusion in Society is detrimental to their psychology. On the other hand, men try to find solutions, even if they think they are experiencing social exclusion because they are raised in a patriarchal culture and have related emotions/behavior patterns. Men perceive the issues as a problem that needs to be solved instead of seeing them as emotional stress or psychological distress. The strategy they have developed to solve this problem is to continually talk to Turkish citizens and develop discourse to change the perceptions they perceive as "wrong" in Society.

As for the questions asked in the section of the study's aim, at a certain extent, Syrian Youth integrated into Turkish Society by learning Turkish and adapting some things such as working life, culture, lifestyle, and Turkish people's friendships. It can be said that because Islam is common between two societies, the integration has been much easier than other societies that have different religion and traditions. Although there are some minor criminal issues and exclusions between two societies, the majority of Syrian People feel themselves at their homes. Since Syrians have spread into different parts of Turkey and have had Turkish neighbors, they are pretty socially included in the Society. It can be understood from literature (Milliyet, 2016) that the majority of the Syrian People don't want to go to their countries even if the conflict in Syria finishes.

After eight years of conflict in Syria and because of a huge number of Syrian refugees in Turkey, it is understood that the financial and social burden resulting from free education and free health services on the Turkish Government and Turkish Society is enormous. Even though there are some advantages of Syrian People in Turkey such as increasing demand for products and services in domestic markets and higher exporting capacity by reducing labor costs (Ozturk, Coltu, 2018; Haberturk, 2017), the Syrian issue is being used thoroughly negatively and exploited by politicians and some Turkish People. In this sense, some Turkish people's behaviors and discourses towards Syrian People create pressure on them and make them more socially excluded. On the one side, to eliminate negative behaviors and discourses of some Turkish towards Syrians, the government and NGOs have been working and sometimes collaborating on the exclusion and integration issue. On the other side, especially Syrian Youth try to use the benefits of free education to increase their Turkish language skills and education level to be included in Society easily.

Some Syrian youth face serious difficulties because they are unregistered, do not attend a school or drop out of formal education, cannot receive psycho-social support, and their current poverty situation is poor. Also, it increases the tension between Turks and Syrian youth in the cities due to the current economic problems like high unemployment rates and the abuse of this in daily politics. The number of Syrian youth people ages 18 and under are 1.8 million in Turkey (ICG, 2019). There is a concern that these young people are a lost generation prone to crime. Syrian youth, who face the risk of exclusion, are also likely to join terrorist organizations. Therefore, if the risks Syrian youth will be exposed to today and in the future are not considered, the problems in the society they live in will increase.

Syrians are confronted with more exclusion than citizens of the host country. Among Syrians, women, young people, and those who have to work are more at risk of exclusion. For this reason, comprehensive infrastructure and adaptation policies need to be developed to meet urgent needs in areas such as health, education, housing, and employment. Besides, institutions that support these policies should be established and encouraged.

The main suggestion that emerges with the study's findings is that the education and joining labor markets of Syrian Youth should be encouraged. In this way, they can easily interact with the Society. By increasing and offering education opportunities, Syrian Youth will improve their Turkish, have diplomas and look for alternative formal settings for the future. Encouraging young people to enter the labor markets, both during and after their education, will ensure their integration with the Turkish society. In this sense, a compact approach that plans not only the education process but also the post-education process should be put forward. Although Syrian Youth are affected by the negative discourses and social exclusions by some people and politicians, they still see themselves as individuals in this Society by establishing a connection with the Society. The difficulties that Syrian People have been confronted with related to daily life interaction should be explained and shared with Turkish People by using mainstream media channels such as TV, Radio, Internet, and Social Media. By doing that, the awareness of Turkish People towards the challenges of Syrian People will be increased, and more empathy will be done.

Although Syrians are Muslims like Turkish society, problems arise from time to time due to cultural and political differences and economic difficulties. Even if the war is over in Syria, many Syrians will want to stay in Turkey. Therefore, a new adaptation program is needed for Syrians and Turks to live together with the facts and reduce mutual prejudices. The program, aiming to eliminate the unreal obstacles and discourses for the future common life of Turks with Syrians, with their religious, historical, and cultural similarities, should be implemented. For this, the existence of a governance understanding with the cooperation of the private sector, civil society, and the state should be.

Author contributions: All co-authors have involved in all stages of this study while preparing the final version. They all agree with the results and conclusions.

Funding: No external funding is received for this article.

Declaration of interest: The authors declare that they have no competing interests.

Ethics approval and consent to participate: Not applicable.

Availability of data and materials: All data generated or analyzed during this study are available for sharing when appropriate request is directed to corresponding author. 


\section{REFERENCES}

Akhtar, S. (2018). Göç ve kimlik; Kargaşa, sağaltım ve dönüşüm [Immigration and identity; Confusion, treatment, and transformation]. Istanbul: Sfenks Books.

Deniz, A. Ç., Ekinci, Y., \& Hülür, A. B. (2016). Bizim müstakbel hep harap oldu, Suriyeli sığınmacıların gündelik hayatı Antep-Kilis çevresi [Our future is always devastated, the daily life of Syrian refugees around Antep-Kilis]. Istanbul: Istanbul Bilgi University Publications.

Ekinci, Y. (2015). Misafirlik dediğin üç günlük olur!”: Suriyeli sığınmacılar ve sosyal dışlanma [What you call a guest is for three days!": Syrian refugees and social exclusion]. Birikim Dergisi (311).

Erbaş, H. (2019). Gidişlerden kaçışlara göç ve göçmenler; Kuram, yöntem ve alan yazılarl [Immigration and immigrants from departures to fleeing; Theory, method and field articles]. Ankara: Phoenix Publisher.

Eren, E. Y. (2018). Mülteci hukukunda geçici koruma [Temporary protection in refugee law]. Ankara: Seçkin Yay.

Goffman, E. (2014). Damga; örselenmiş kimliğin idare edilişi üzerine notlar [Stamp; Notes on the handling of damaged identity]. Ankara: Heretik Yayıncılık.

Goffman, E. (2018a). Karşılaşmalar, etkileşim sosyolojisinde iki çalışma [Encounters, two studies in the sociology of interaction]. Ankara: Heretik Publications.

Haberturk. (2017). Suriyelilerin Türkiye ekonomisine etkisi araştırıld $ı$ [The impact of Syrians on the Turkish economy was investigated]. Available at: https://www.haberturk. com/suriyelilerin-turkiye-ekonomisine-etkisi-arastirildi1628337-ekonomi

Hayata Destek Derneği. (2016). Istanbul'daki Suriyeli mültecilere ilişkin zarar görebilirlik değerlendirme raporu [Vulnerability assessment report on Syrian refugees in Istanbul]. Available at: https://www.hayatadestek.org/wpcontent/uploads/2019/06/istanbuldaki-suriyelimulteciler-zarar-gorebilirlik-raporu.pdf

ICG. (2019). Mitigating risks for Syrian refugee youth in Turkey's Şanlıurfa. International Crisis Group, Crisis Group Europe Report N²53, 11 February 2019.

Istanpol, Istanbul Politik Araştırmalar Enstitüsü. (2019). 24 Haziran'dan 31 Mart'a, iki seçim arası Türkiye'de siyasal kutuplaşma [Between 24 June and 31 March, political polarization in Turkey between two elections].
Milliyet. (2017). Suriyelilerin \% 62'si gitmek istemiyor [62\% of Syrians do not want to go]. Available at: http://www.milliyet.com.tr/siyaset/suriyelilerin-62-sigitmek-istemiyor-2363610

Mülteciler Derneği. (2019). Türkiyedeki Suriyeli sayısı Eylül 2019 [Number of Syrians in Turkey September 2019]. Available at: https://multeciler.org.tr/turkiyedeki-suriyelisayisi/

Neil, S. (2008). Places of Exclusion and Inclusion: AsylumSeeker and Refugee Experiences of Neighbourhoods in the UK. Journal of Ethnic and Migration Studies, 34(3), 491-510. https://doi.org/10.1080/13691830701880350

Ozturk, S. and Coltu, S. (2018). Suriyeli mültecilerin Türkiye ekonomisine etkileri [The effects of Syrian refugees on the Turkish economy]. Balkan Journal of Social Sciences/Balkan Sosyal Bilimler Dergisi, 7(13), 188-198.

Phillimore, J. and Goodson, L. (2006). Problem or Opportunity? Asylum Seekers, Refugees, Employment and Social Exclusion in Deprived Urban Areas. Urban Studies, 43(10), 1715-1736. https://doi.org/10.1080/00420980600838606

Phillimore, J., Goodson, L., Ferrari, E., Oosthuizen, E., Fathi, J., Penjwini, S. and Joseph, R. (2003). Asylum seekers and refugees: education, training, employment, skills and services in Coventry and Warwickshire. Learning and Skills Council Coventry and Warwickshire, Coventry.

Saleh, A., Aydin, S. and Koçak, O. (2018). A comparative Study of Syrian Refugees in Turkey, Lebanon, and Jordan: Healthcare Access and Delivery. OPUS Uluslararası Toplum Araştırmaları Dergisi, 8(14), 448-464. https://doi.org/ 10.26466/opus.376351

Sari Hanafi, Jad Chaaban, Karin Seyfert, (2012). Social Exclusion of Palestinian Refugees in Lebanon: Reflections on the Mechanisms that Cement their Persistent Poverty. Refugee Survey Quarterly, 31(1), 34-53. https://doi.org/ 10.1093/rsq/hdr018

Şener, S. (2013). Sosyoloji, sosyal bilimlere alternatif yaklaşım [Sociology, alternative approach to social sciences]. Istanbul: Inkilab Publications.

Taylor, J. (2001). Refugees and social exclusion: what the literature says. Migration Action, XXVI(2), 16-31.

Taylor, J. and Stanovic, D. (2004). Services and entitlements: Refugees, migrants and asylum seekers. Migration Action, $X X V I(2)$. 